\title{
The Paradox of Being Human and more than Human: Exploring the Class Struggle in Nancy Kress' Beggars in Spain
}

\author{
Ms. Chithra J.L., \\ Former Faculty, Dept. of English, BJ CSI Arts and Science College, Mulayara, Thiruvananthapuram, Kerala.
}

\section{ABSTRACT:}

The human history is an apologue. It tells the struggle-some tale of races, aiming for power and prestige or for mere survival. Marxism, discontent with the existing struggle between the haves and have-nots, envisages a classless society. Science fiction, in contrast, assumes a fictious world, not of humans alone, but of a macrocosm of living and non-living creatures including human, non-human or subhuman entities. When the divergent communities co-exist within the same planet, there arises a dissonance. Posthuman theory assumes that "the dividing line between human, non-human or the animal is highly permeable." There is quite a good number of Science fictions that conjures up towards a posthuman future. Even though, seemingly divergent aspects, Marxian and Posthuman theory, both presumes a fictional world. The first surmises on an ideal utopia of class-less society of unique economic equality, the second foresees a futuristic world of humans- less than or more than 'humans.' Nancy Kress' Beggars in Spain is a typical science fiction which tells the negative impact of genetic engineering. A few fortunate parents who could afford the expensive genetic engineering, was able to brought about a new generation of sleepless children with unique features. But those without any alterations, remained as sleepers. In the long run, the ordinary humans seemed to lose the race with the much productive individuals, who is having a bonus of sleeping hours and much more added advantages. The conflict results in a class struggle of 'haves and have-nots'. Marxian view of the class struggle between the proletariat and the aristocrats can be analyzed on par with the classification of individuals purely based on their talents whether they inherited or purposefully custom-made. The present scrutiny rounds off the assertion that, there is no ultimate victory over the war of human and posthuman races.

Key-words:Marxism, Posthumanism, class-struggle, science fiction, genetic engineering, etc.

Article Received: 18 October 2020, Revised: 3 November 2020, Accepted: 24 December 2020

"It is pretty ironic that the so-called 'least advanced' people are the ones taking the lead in trying to protect all of us, while the richest and most powerful among us are the ones who are trying to drive the society to destruction" - Noam Chomsky.

Marxism and Science fiction are seemingly divergent aspects. Marxism aims at realizing a classless society on earth that we live in. Science fiction on the other hand, foresees a futuristic world, not only of normal humans but of, genetically modified organisms as well as extra-terrestrial creatures. The common feature that both of which share is rationality even though abounds with an element of fiction. Nancy Kress' Beggars in Spain is a typical science fiction which tells the negative impact of genetic engineering. It undermines the class struggle between the genetically modified intelligent and highly productive community of "sleepless" and the normal humans or the "sleepers".
A few fortunate parents who could afford the expensive genetic engineering, was able to brought about a new generation of sleepless children with unique features. But the children of the lesser gods are left as such without any sophistication, still the sleepers. In the long run, the ordinary humans seemed to lose the race with the much productive individuals, who is having a bonus of sleeping hours and much more added advantages. Ultimately, the rift between the superior minority and the less privileged result in a class struggle of 'haves and have-nots'. Marxian view of the class struggle between the proletariat and the aristocrats can be analyzed on par with the classification of individuals purely based on their talents whether they inherited or purposefully custommade.

Likely to a "utopian" world of social equality that Marxism envisages, Beggars in Spain caricatures a unique society -- a world in which genetic 
engineering is prevalent. The society now bears the consequences of genetic-modifications, otherwise known as 'genemods'especially in the United States. Their major source of power is called "Y-energy" propounded by Kenzo Yagai, a kind of energy produced through cold fusion (that is, the mythical low energy nuclear reaction at room temperature). The crux of this sf deploys "Yagaiism", a typical social order in which people accomplish worth and value, solely in accordance with their personal ability to manifest achievements of their own. As a result, the weak and the unproductive become the least accounted in such a social order. In fact, Kress' adherence to philosophy of Objectivism advocated by the RussianAmerican writer Ayn Rand is explicit. According to Rand's Objectivism, "the concept of man as a heroic being, with his own happiness as the moral purpose of his life, with productive achievement as his noblest activity and reason as the moral purpose of his absolute".

Leisha Camden, is one among the human beings who have the modified genetic structure for sleeplessness. She is the daughter of a multimillionaire Roger Camden, a well-known sponsor to Yagai, who felt it unnecessary to sleep and waste much of the productive time. This aspect is parallel to the Althusser's influential Marxian concept of 'overdeterminism'. Sleeplessness confers a number of secondary benefits like higher IQ as well as much productive time.

Leisha became a member of the sleepless community. This platform gives them an opportunity to share their common problems and to seek solutions. Like Leisha Camden, Kevin barker, the oldest among the sleepless and a wealthy software designer, Rich Keller who becomes her lover and Tony Indivino, whose mother forces him to live as a sleeper are some sleepless who cannot sleep. Tony predicts the upcoming discriminations of the sleepless. He also promotes them to unite for building up a community of the sleepless for socio-economic benefits. Tony was accused and jailed by the sleepers for illegal actions but Jennifer Sherifi, daughter of a movie star and Arab oil giant purchases land for a sleepless-only community known as 'Sanctuary'. This attempt can be seen as a step towards building up of 'socialist commune' based on the Marxian theory.
Susan Melling, the genetic researcher who devised sleeplessness, reveals that the sleepless is having the trait of cell-regeneration which will confers the sleepless immortality. All these unique features of the sleepless pause an emerging threat to the existing social order. There arises tensions and ultimately leads to an unavoidable 'class-struggle' between the common people on earth who makes the 'base' and 'the super structure' consisting of the sleepless minority.

The novel centres around the emphatic question: "what do productive and responsible members of society owe the 'beggars in Spain', the unproductive masses who have nothing to offer except need?". The sleepless become unbeatable in their talents. They tend to manifest a much productive world. In every walks of life the society of the sleepless outwit the normal humans. That means, the Sleepless emerge as a 'hegemonic' power. Meanwhile, the sleepers struggle for a 'relative autonomy'. Their struggle for survival results in acts of violence and bloodshed and which culminated in the outrageous "We-Sleep" movement.

The 'Sanctuary' erected by the sleepless for protecting the communal rights is a kind of ideological structure or 'the state ideological apparatus' in terms of Marxian theory. The Sleepless also takes oath of solidarity as a token of their adherence to the particular ideology. Leisha as an advocate of peace between the two sects, was viewed as a traitor to them, even though she is genetically sleepless and she is expelled by the 'repressive structure' of the sleepless to the extend, her partner Kevin Barker takes oath in solidarity to the sleepless and abandons her.

The social order changes dramatically with a three-tiered social structure. The "Livers" who are eighty percent of the population, under-educated but well-fed and enjoys a life of pleasure were placed at the bottom of the social strata. The "donkeys" who were the elected representatives of the Livers, and the gene-mod white-collar force that are the office-bearers of the Livers earning vote through bread and circuses. On the top comes the Sleepless, the primary source of all scientific, technological advancements and progress. 
A kind of "Superbrights" a most updated version of the Sleepless with three or four times faster in brain functioning than the standard sleepless themselves emerges. They think differently than the sleepless. They are relentlessly sleeper-haters and they even obsessed with declaring Sanctuary, the regime of the sleepless is independent of the United States. Later on it was detected that the Superbrights have some conceptual flaws in their genetic make-up. At the same time the Sleepless consider the Superbright as a threat to their existence. Later on, the Superbrights could rectify their draw backs and bring about a number of ground breaking discoveries and inventions in the fields of medicine, science and technology. While the Sleepless who were called the 'beggars' by the Superbrights, they get hold of the bioweapon advanced by their counterparts and install at different parts of the US that they live in.

The Sanctuary proclaims independence from the United States thereafter. All human tenants were evacuated and bio-weapon was used for demonstration. Finally, it was found that "all of Sanctuary's political philosophy ... comes down to personal needs". In this juncture, the turn of events can be compared with that of the similar situation that arises in the factious world created by George Orwell's Animal Farm. As the novel winds up, the Superbrights move towards the Susan Melling Foundation. At last it was proved that there is no permanent 'beggars in Spain'. The fiction ends with the note that the inhabitants, even when strategically tries to outperform, are not immune to the ultimate world order.

The Marxian theory of interpellation advocated by Althusser can be considered with respect to Nancy Kress' Beggars in Spain -- the world of the Sleepers and the Sleepless. In Althussar's terms, the society is driven by the Ideological State Apparatuses of the genetically modified and highly productive few. As a result, they use Repressive State Apparatus to control the normal humans who are in truth, makes the majority of the world. Ultimately, it was proved that both of them have no choices but, they are as individual subjects, "hailed" as part of or being instrumental to the hidden ideology.
There is no ultimate victory in the battle of the races. The beggars no longer left as such. The 'class struggle' for imparting power, the 'over determinism' of a few moved by a certain 'ideology', the concept of 'relative autonomy', the 'decentering' of social order, the 'ideological structures' erected by the prominent race as a token to expel their 'hegemonic' power and the 'interpellation' when there is no choices at a juncture - all points to the possibility of the Marxian reading of Nancy Kress' Beggars in Spain .

\section{Works Cited:}

1. Abrams, Meyer Howard, and Geoffrey Harpham. A glossary of literary terms. Nelson Education, 2014.

2. Barry, Peter. Beginning theory: An introduction to literary and cultural theory. Manchester university press, 2020.

3. Buchanan, Ian. A dictionary of critical theory. Oxford University Press, 2018.

4. Csicsery-Ronay, Istvan. Marxist theory and science fiction, 2003.

5. Forster, Edward Morgan. Aspects of the Novel. Vol. 19. Houghton Mifflin Harcourt, 1985.

6. Herbrechter, Stefan. Posthumanism: A critical analysis. A\&C Black, 2013.

7. JL, Chithra. "Inevitably Posthuman: An Appraisal through Literature." Journal of the Gujarat Research Society 21.10 (2019): 281286.

8. Kress, Nancy. Beggars in Spain. Eos, 2004.

9. Bould, Mark, et al., eds. The Routledge companion to science fiction. Routledge, 2009.

10. goodreads.com/book/show/68333.Beggars_in_ Spain

11. jolindsaywalton.blogspot.com/2015/06/marxis $\mathrm{t}$-science-fiction-studies.html

12. publishersweekly.com/978-0-688-12189-1 